\title{
Intracardiac Thrombosis and Coronary-to-Pulmonary Artery Fistula with Pulmonary Embolism and Budd-Chiari Syndrome in Behçet's Disease: A Case Report
}

\author{
Behçet Hastalığında Pulmoner Emboli ve Budd-Chiari Sendromu ile Seyreden Kalp İçi \\ Trombüs ve Koroner-Pulmoner Arter Fistülü: Olgu Sunumu
}

\author{
Tolga AKSU, ${ }^{1}$ Ayşegül ÖZ ${ }^{2}$ \\ ${ }^{1}$ Department of Cardiology, Kocaeli Derince Training and Research Hospital, Kocaeli, Turkey \\ ${ }^{2}$ Department of Radiology, Medical Faculty of Hacettepe University, Ankara, Turkey
}

\begin{abstract}
Behçet's disease (BD) is a multisystemic, chronic and inflammatory vasculitis presentation. A 29-year-old male patient with BD was admitted to our clinic with dyspnea and chest pain. On his physical examination, a left parasternal murmur resembling the sound of a machine was detected along with abdominal ascites. The patient's electrocardiography and chest X-ray were normal. Thoracic computed tomography (CT) revealed a chronic pulmonary embolism. On abdominal CT, a thrombus was detected in the hepatic vein and inferior vena cava, which was consistent with Budd-Chiari syndrome (BCS). Twodimensional transthoracic echocardiography demonstrated a mass on the right atrium protruding into the right ventricle. On the suprasternal view, abnormal flow surrounding the arcus aorta and pulmonary artery was detected. Coronary angiography showed a fistula formation between the left main branch and pulmonary artery. A treatment with anti-inflammatory drugs and heparin was initiated. Complete recovery of the pulmonary embolism and intracardiac thrombosis were observed at six months. In this article, we present a BD patient with intracardiac thrombosis and coronary-to-pulmonary fistula associated with a pulmonary embolism and BCS.
\end{abstract}

Key words: Behçet's disease; fistula; pulmonary embolism; thrombus.

Behçet's disease (BD) is a systemic inflammatory disorder of unknown cause. ${ }^{[1]}$ Although large venous and arterial lesions occur with it, intracardiac thrombus formation is uncommon.
Behçet Hastalığı (BH) multisistemik, kronik ve inflamatuvar vaskülit tablosudur. Behçet hastalığı olan 29 yaşında erkek hasta dispne ve göğüs ağrısı ile kliniğimize başvurdu. Hastanın fizik muayenesinde sol parasternal -makine sesine benzer- bir üfürüm ve abdominal asit saptandı. Hastanın elektrokardiyografi ve gögüs röntgen sonuçları normaldi. Toraks bilgisayarlı tomografide (BT) kronik pulmoner emboli izlendi. Abdominal BT'de BuddChiari sendromu (BCS) ile uyumlu olarak hepatik ven ve inferior vena kavada trombüs izlendi. İki boyutlu transtorasik ekokardiyografide sağ atriyumdan sağ ventriküle uzanım gösteren kitle izlendi. Suprasternal pencerede arkus aortu ve pulmoner arteri çevreleyen anormal akım tespit edildi. Koroner anjiyografide sol ana koroner arter ile pulmoner arter arasında fistül oluşumu gözlendi. Antiinflamatuvar ilaçlar ve heparin tedavisi başlandı. Altıncı ayda pulmoner emboli ve kalp içi trombüste tam düzelme izlendi. $\mathrm{Bu}$ yazıda $\mathrm{BH}$ olan bir hastada kalp içi trombüs, Budd-Chiari sendromu ve pulmoner emboli ile ilişkili koroner-pulmoner arter fistülü birlikteliği sunuldu.

Anahtar sözcükler: Behçet hastalığı; fistül; pulmoner emboli; trombüs.

We report a manifestation of $\mathrm{BD}$ with intracardiac thrombosis (ICT) and coronary-to-pulmonary fistula, a pulmonary embolism (PE), and Budd-Chiari syndrome (BCS) in which the patient recovered

Received: June 26, 2012 Accepted: October 08, 2012

Correspondence: Tolga Aksu, M.D. Kocaeli Derince Eğitim ve Araştırma Hastanesi, Kardiyoloji Kliniği, 41900 Derince, Kocaeli, Turkey.

Tel: +90 262 - 3178000 / 2407 e-mail: aksutolga@gmail.com

(C)2013 Turkish League Against Rheumatism. All rights reserved. 
completely after being treated with colchicine, methylprednisolone, cyclophosphamide, and intravenous heparin.

\section{CASE REPORT}

A 29-year-old male patient with BD was admitted to our clinic with dyspnea, palpitations, and chest pain. The diagnosis had been established three years earlier on the basis of mucocutaneous lesions and gastrointestinal disorders. The patient had then been treated with colchicine and corticosteroids. His past medical history also included deep venous thrombosis (DVT) in his calf. On his physical examination, a left parasternal murmur resembling the sound of a machine was detected along with abdominal ascites. His electrocardiography (ECG) and chest X-ray results were normal. Post-contrast thoracic computed tomography (CT) revealed right pulmonary effusion and decreased calibration together with a filling defect of the left inferior pulmonary artery due to a chronic PE (Figure 1a). On the abdominal ultrasononography, hepatic venous thrombosis was detected. The portal venous system was patent, but no enhancement was detected in the hepatic veins or proximal inferior vena cava (IVA) on the abdominal CT. The findings were concordant with BCS (Figure 1a). Two-dimensional transthoracic echocardiography revealed a mass on the right atrium protruding into the right ventricle (Figure 2a). The suprasternal view showed a turbulent and abnormal flow surrounding the arcus aorta and pulmonary artery (Figure 2b). Doppler interrogation demonstrated a continuous flow signal at that location. In addition, coronary angiography was performed to evaluate coronary involvement because of intractable angina pectoris, and a coronary arteryto-pulmonary artery fistula was detected arising from the left coronary artery (LCA) (Figure 3). On cardiac catheterization and oximetry study, there was a 5\% step-up between the right ventricle and distal pulmonary artery, and the left-to-right shunt was 1.3. Since there was no evidence of a significant shunt, the fistula was not thought to be the cause of the angina, and the patient did not undergo corrective intervention. During the sixth month of treatment with colchicine, methylprednisolone, cyclophosphamide, and heparin, thoracic CT revealed complete lysis of the pulmonary thrombosis and ICT.

\section{DISCUSSION}

Cardiovascular involvement has been reported in 7-46\% of BD patients. ${ }^{[2]}$ There are three categories of vascular lesions in $\mathrm{BD}$ : arterial occlusion, arterial aneurysms,
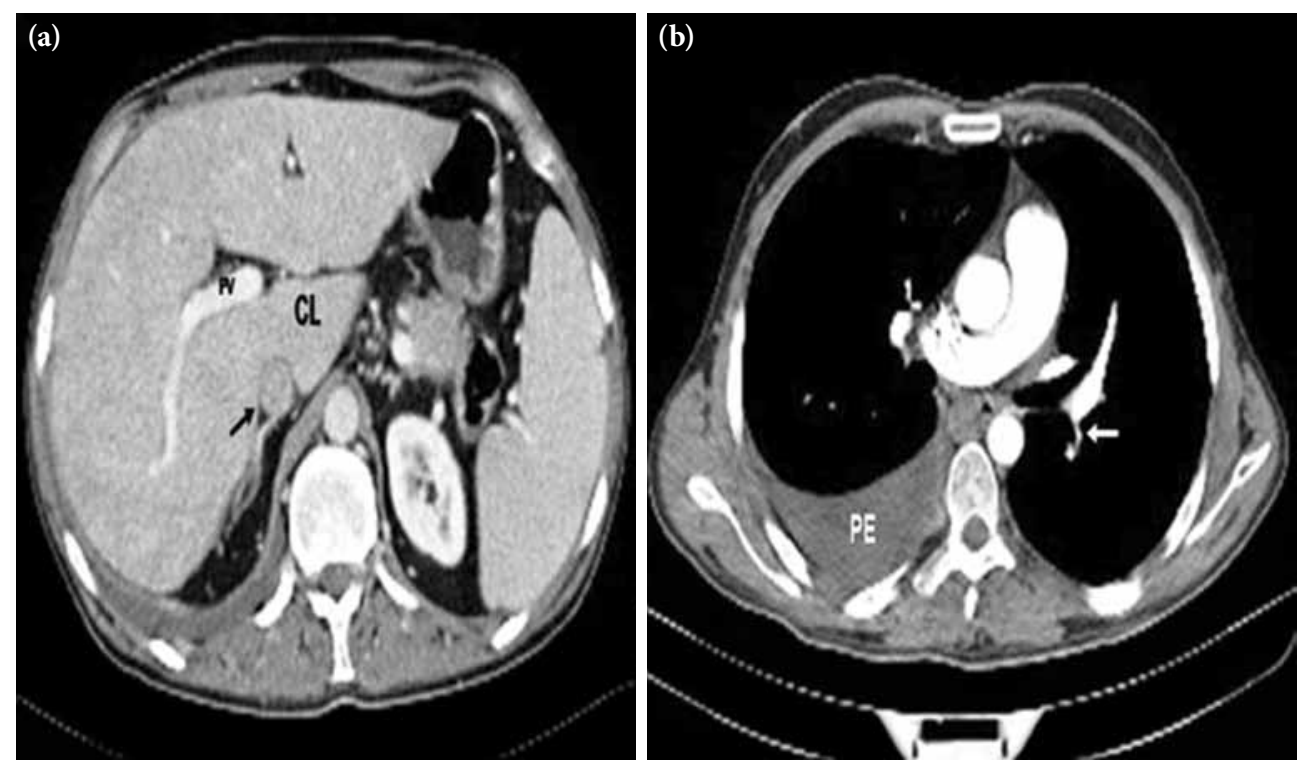

Figure 1. (a) Intravenous contrast-enhanced abdominal computed tomography of $5 \mathrm{~mm}$ slice thickness with a transverse plane in the venous phase. Contour irregularity and hypertrophy of the caudate lobe sustain chronic liver disease. Venous parenchymal enhancement is heterogenous, and the portal system is patent. No enhancement is detected in the hepatic veins or proximal inferior vena cava. All findings are concordant with Budd-Chiari Syndrome. (b) Post-contrast thoracic computed tomography of $3 \mathrm{~mm}$ slice thickness with a transverse plane in the pulmonary arterial phase. There is decreased calibration and a filling defect of the left inferior pulmonary artery due to chronic pulmonary embolism (white arrow). CL: Caudate lobe; PV: Portal vein; PE: Pleural effusion. 

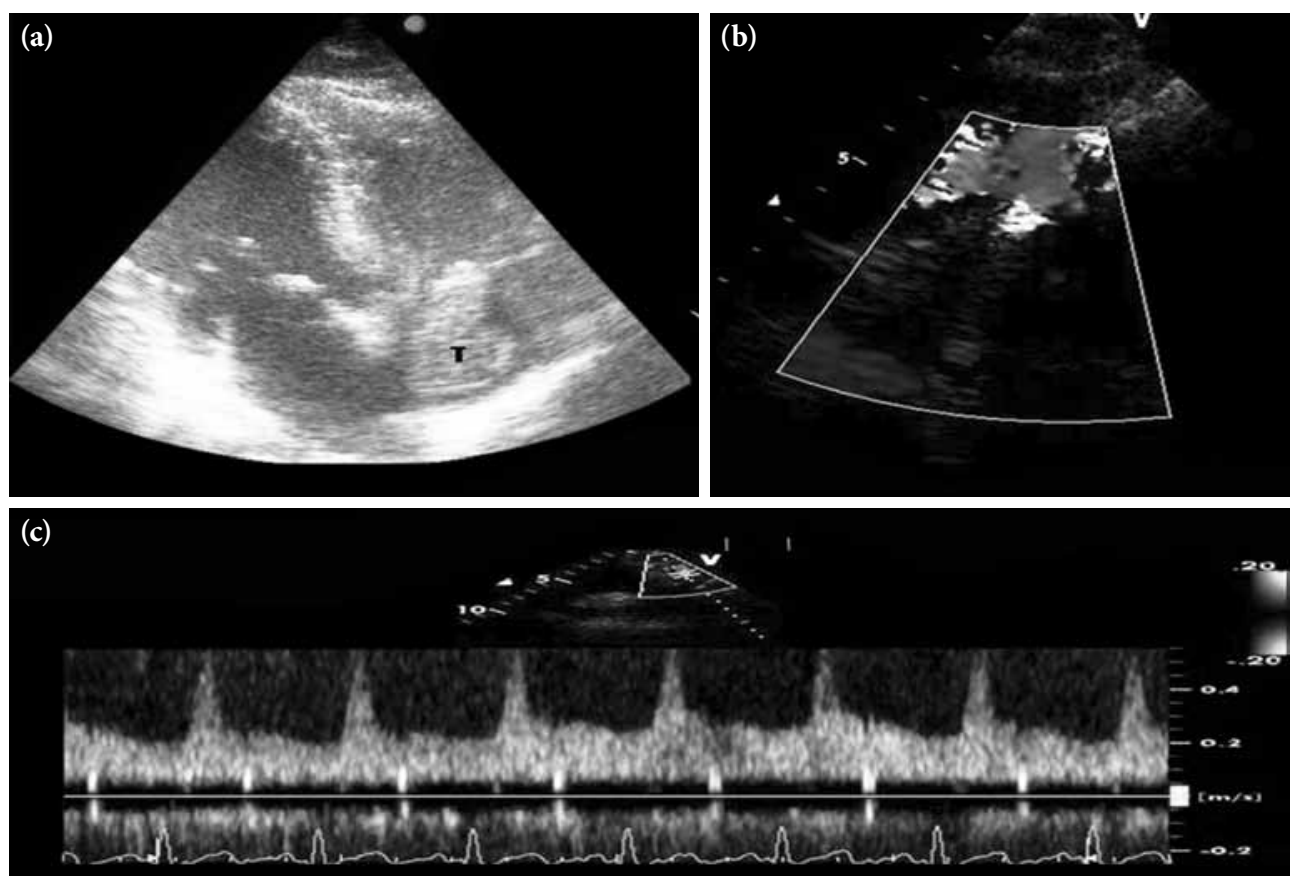

Figure 2. (a) Transthoracic echocardiography showing a mobile echo ( $\mathrm{T}$ ) on the right atrium that protrudes to the right ventricle. (b) Color flow Doppler showing local flow acceleration and turbulence expressed as color aliasing that is consistent with a fistula. (c) Doppler interrogation demonstrating a continuous flow signal.

and venous occlusions. ${ }^{[3]}$ Pulmonary involvement is secondary to vasculitic lesions and includes stenosis, occlusions, and aneurysms. ${ }^{[4]}$ Data regarding treatment and outcomes of patients having BD-related pulmonary emboli and small-sized vasculitis is limited. Computed tomography angiography is noninvasive and provides excellent delineation of the vessel lumen and wall as well as the perivascular tissues for the diagnosis of vascular complications.

Coronary-to-pulmonary artery fistulas are usually congenital in origin. Edwars ${ }^{[5]}$ classified

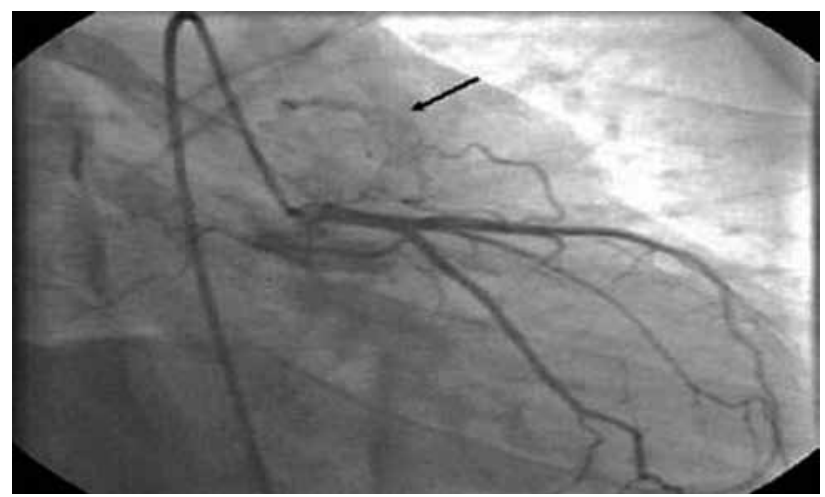

Figure 3. Selective coronary angiogram demonstrating the fistula (arrow) from the left anterior descending artery to the conus of the pulmonary artery in the right anterior oblique projection. them into two types: the primary fistula, in which the fistula is the main pathological lesion, and the secondary fistula, which occurs as a consequence of other malformations. In our case, we hypothesized that the fistula formation may be a collateral circulation due to a chronic PE. The abnormal vessel, as detected in our patient, may arise from the coronary artery at any level, ${ }^{[6]}$ and the hemodynamic effect of the left-to-right shunt is related to the size of the shunt and pulmonary vascular resistance. The presence of a fistula may lead to a decreased amount of blood perfusing the myocardium, and this may result in angina, myocardial infarction (MI), or papillary muscle dysfunction. ${ }^{[7]}$ Selective coronary angiography is the most accurate diagnostic tool and usually demonstrates evidence of the origin, course, size, and termination of the fistula. Closure treatment is usually indicated in patients with severe symptoms that cannot be controlled by medical treatment. However, the method of treating asymptomatic patients with coronary artery fistulas is more controversial. ${ }^{[7]}$ Our BD patient had ICT and a PE with coronary-topulmonary artery fistula in conjunction with BCS. There was no significant shunt in our case, so no intervention was considered. 
Intracardiac thrombosis is an uncommon complication of BD. Only 66 cases of $\mathrm{BD}$ patients with ICT have been reported in the literature. ${ }^{[8]}$ The right heart is the most common localization for the thrombosis, but the reason for the frequency of rightsided ICT associated with BD is still unknown. Soulami et al. ${ }^{[9]}$ postulated that endomyocardial fibrosis has a role in the development of ICT in some patients. Endothelial dysfunction, the release of von Willebrand factor (vWF), platelet activation, enhanced thrombin and fibrin generation, antithrombin deficiency, and impaired fibrinolysis close the pathological chain of enhanced thrombocoagulation associated with vasculitis (perivasculitis) in $\mathrm{BD} \cdot{ }^{[10]}$

However, it is difficult to know whether the thrombi are secondary to the underlying endocarditis or endomyocardial fibrosis. There is no consensus regarding the treatment of cardiac thrombosis in association with $\mathrm{BD}$. The aim of treatment is to control the underlying disease and to resolve the cardiac thrombus. Anticoagulant and antithrombotic agents are the first line of therapy. ${ }^{[1]}$ Routine anticoagulation with heparin or oral anticoagulants is not advised, but anticoagulant treatment together with immunosuppressive therapy is an advised treatment option in Behçet's cases with ICT. As with pulmonary artery aneurysm (PAA), a combination of cyclophosphamide and methylprednisolone is most frequently prescribed for patients with severe vasculitis, but in patients with $\mathrm{BD}$, the PAA may become smaller or disappear with medical treatment. ${ }^{[12]}$ Occlusion of the hepatic portion of the IVC, major hepatic vein, or both can lead to BCS, and the prevalence of BCS in BD is $3.2 \%$. Behçet's disease is an uncommon cause of BCS, and only 56 cases of BD complicated by BCS have been published. ${ }^{[3]}$ However, the BCS can be treated medically, interventionally, or surgically.

In conclusion, when investigating the possible etiology of ICT, pulmonary PE, and BCS in a patient, BD should be kept in mind. In addition, immunosuppressive treatment along with anticoagulants can be used in $\mathrm{BD}$ patients with vascular disease.

\section{Declaration of conflicting interests}

The authors declared no conflicts of interest with respect to the authorship and/or publication of this article.

\section{Funding}

The authors received no financial support for the research and/or authorship of this article.

\section{REFERENCES}

1. Hirohata S, Kikuchi H. Behçet's disease. Arthritis Res Ther 2003;5:139-46.

2. Gürgün C, Ercan E, Ceyhan C, Yavuzgil O, Zoghi M, Aksu K, et al. Cardiovascular involvement in Behçet's disease. Jpn Heart J 2002;43:389-98.

3. Ben Ghorbel I, Ennaifer R, Lamloum M, Khanfir M, Miled M, Houman MH. Budd-Chiari syndrome associated with Behçet's disease. Gastroenterol Clin Biol 2008;32:316-20. doi: 10.1016/j.gcb.2007.12.022.

4. Uzun O, Akpolat T, Erkan L. Pulmonary vasculitis in Behçet disease: a cumulative analysis. Chest 2005;127:2243-53.

5. Edwards JE. Anomalous coronary arteries with special reference to arteriovenous-like communications. Circulation 1958;17:1001-6.

6. Buxton B, Ventimeglia R, Reul GJ, Cooley DA. Congenital coronary-to-pulmonary artery fistula: diagnosis and treatment. Cardiovasc Dis 1976;3:202-209.

7. Effler DB, Sheldon WC, Turner JJ, Groves LK. Coronary arteriovenous fistulas: diagnosis and surgical management. Report of fifteen cases. Surgery 1967;61:41-50.

8. Aksu T, Tufekcioglu O. Intracardiac thrombosis in Behcets disease. Four new cases and a metaanalysis. Euroecho 2008. 10-13 December, 2008, Lyon, France; 2008.

9. La Regina M, Gasparyan AY, Orlandini F, Prisco D. Behçet's Disease as a Model of Venous Thrombosis. Open Cardiovasc Med J 2010;4:71-7. doi: 10.2174/1874192401004020071.

10. Cocco G, Gasparyan AY. Behçet's Disease: an Insight from a Cardiologist's Point of View. Open Cardiovasc Med J 2010;4:63-70. doi: 10.2174/1874192401004020063.

11. Mogulkoc N, Burgess MI, Bishop PW. Intracardiac thrombus in Behçet's disease: a systematic review. Chest 2000;118:479-87.

12. Tunaci M, Ozkorkmaz B, Tunaci A, Gül A, Engin G, Acunaş $B$. CT findings of pulmonary artery aneurysms during treatment for Behçet's disease. AJR Am J Roentgenol 1999;172:729-33. 